\title{
Hepatoprotective effect of Cinnamon extracts against carbon tetrachloride induced oxidative stress and liver injury in rats
}

\author{
SAID S. MOSELHY ${ }^{1}$ and HUSEIN K. H. ALI ${ }^{2}$ \\ ${ }^{1}$ Department of Biochemistry, Faculty of Science, Ain Shams University, and \\ ${ }^{2}$ Zoology Department, Faculty of Science, Alexandria University, Cairo, Egypt.
}

\begin{abstract}
Cinnamon is used to flavor most foods in Arabian countries. The aim of this study was to evaluate the medicinal importance, reflecting an important trend in research. The hepatoprotective activity of aqueous and ethanolic extracts of cinnamon was investigated against carbon tetrachloride $\left(\mathrm{CCl}_{4}\right)$ induced lipid peroxidation and hepatic injury in rats. The elevated serum AST and ALT enzymatic activities induced by $\mathrm{CCl}_{4}$ were significantly restored to near normal by oral administration of $200 \mathrm{mg} / \mathrm{kg}$ of either extracts once daily for 7 days, as compared to untreated rats. There was a significant elevation in the level of liver malondialdhyde (MDA), while the activities of antioxidant enzymes superoxide dismutase and catalase (SOD and CAT) were significantly decreased in $\mathrm{CCl}_{4}$ intoxicated rats. The results obtained indicated that ethanolic extract has more potent hepatoprotective action than water extract against $\mathrm{CCl}_{4}$ by lowering the $\mathrm{MDA}$ level and elevating antioxidants enzymes activities (SOD and CAT). The possible mechanism of this activity may be free radical-scavenging polyphenol compounds. The hepatoprotective properties were documented by the histopathological data obtained. Consequently, this extract can be used as a therapeutic regime in treatment of some hepatic disorders without any side effects. Further study will be done for separation and identification of active components and for testing antitumor activity.
\end{abstract}

Key terms: Cinnamon extracts, $\mathrm{CCl}_{4}$, oxidative stress, rats.

\section{INTRODUCTION}

Free radicals in the form of reactive oxygen and nitrogen species are an integral part of normal physiology. Over-production of these reactive species can occur, due to oxidative stress brought about by the imbalance of the bodily antioxidant defense system and free radical formation. These reactive species can react with biomolecules, causing cellular injury and even death. They can lead to the development of chronic diseases such as cancers and those that involve the cardioand cerebrovascular systems (Gurdip et al., 2007). The consumption of fruits and vegetables (Peschel et al., 2006) containing antioxidants has been found to offer protection against these diseases. Antioxidants are often added to foods to prevent the radical chain reactions of oxidation, and they act by inhibiting the initiation and propagation step leading to the termination of the reaction and delay the oxidation process (Shahidi et al., 1992).

Cinnamon is a popular flavoring ingredient, widely used in food products. It has exhibited beneficial properties to health, such as antimicrobial activity, for controlling glucose intolerance and diabetes, inhibiting the proliferation of various cancer cell lines, and for treating the common cold (Anderson \& Broadhurst, 2004; Murcia et al., 2004). Cinnamon extracts can reduce lipid peroxidation in the $\beta$-carotene-linoleic acid system, (Mancini-Filho \& Van-Koiij, 1998).

Corresponding author: ${ }^{1}$ Said S. Moselhy. Permanent address: Biochemistry Department, Faculty of Science, Ain Shams University, Cairo, Egypt. Tel. 0020122350263 email: Moselhy6@ hotmail.com, Current address. Biochemistry Department, Faculty of Science, King Abdualziz University, Jeddah, Saudi Arabia. Tel. 00966566991424. 
Cinnamon extracts exhibit a protective capacity against irradiation induced lipid peroxidation in liposomes, and quench hydroxyl radicals and hydrogen peroxide (Murcia et al., 2004). Extracts on lard and vegetable oils demonstrated that they could stabilize lard against oxidation and showed antioxidative properties when tested on vegetable oils during storage or frying conditions (Vekiari, \& Thomopoulos, 1993).

In spite of the tremendous advances in modern medicine no effective drugs are available, which stimulate liver functions and offers protection to the liver from damage or help to regenerate hepatic cells (Chattopadhyay, 2003). In the absence of reliable liver-protective drugs in modern medicine, a large number of medicinal preparations are recommended for the treatment of liver disorders (Chatterjee, 2000) and quite often it is claimed they offer significant relief. The goal of the present study was to examine the antioxidant and hepatoprotective activity of water and ethanolic extracts of cinnamon against oxidative stress induced by $\mathrm{CCl}_{4}$ in rats.

\section{MATERIALS AND METHODS}

\subsection{Animals}

Forty male albino Wister rats weighing (60$80 \mathrm{gm})$ were used in this study .The animals were kept at $27 \pm 2 \square \mathrm{C}$, for 1 week before and during the experiments. Animals were provided with standard diet and water $a d$ libitum.

\subsection{Tested cinnamon}

Cinnamon powder was obtained from the local market at Jeddah, Saudi Arabia.

All reagents and solvents used in this study were purchased from Aldrich Company unless otherwise stated.

\subsection{Preparation of cinnamon extract}

The dried powder was defatted with petroleum ether (100 gm in $200 \mathrm{ml}$ ether). The defatted material was extracted with 95\% ethanol and then vacuum dried. One part of powder was extracted in boiling water and then filtered and vacuum dried.

\subsection{Hepatotoxicity and treated groups.}

Animals were divided into four groups ( $n$ $=10)$. Group I (control). Group II (CCl4) rats were injected with a single dose of $\mathrm{CCl} 4$ in corn oil $(1 \mathrm{~mL} / \mathrm{kg}$ body weight, s.c.) (Avijeet et al.,2008). Groups III and IV were administered $100 \mathrm{mg} / \mathrm{kg}$ of aqueous or ethanolic extracts orally by gastric tube, respectively, in the form of aqueous suspension once daily for 7 days. The animals were then simultaneously administered a single dose of CCl4 $(1 \mathrm{~mL} /$ $\mathrm{kg}$ body weight, s.c.). The animals were sacrificed $24 \mathrm{~h}$ after the last treatment. Blood was collected, allowed to clot and serum was separated at $2500 \mathrm{rpm}$ for 15 min. The livers was dissected out and divided into two parts. The first was kept at $-20^{\circ} \mathrm{C}$ for analysis, while the second part was used for histopathological studies.

\subsection{Serum biochemical assay}

Serum enzymes aspartate aminotransferase (AST) and serum glutamate pyruvate transaminase (ALT) were determined according to (Reitman and Frankel, 1957).

\subsection{Estimation of MDA, SOD, CAT in liver tissue}

Liver samples were dissected out and washed immediately with ice cold saline to remove as much blood as possible. Liver homogenates $(5 \% \mathrm{w} / \mathrm{v})$ were prepared in cold $50 \mathrm{mM}$ potassium phosphate buffer $(\mathrm{pH}$ 7.4) using glass homogenizer in ice. The cell debris was removed by centrifugation at $5000 \mathrm{rpm}$ for 15 at $4^{0} \mathrm{C}$ using refrigerated centrifuge. The supernatant was used for the estimation of malondialdehyde (MDA) (Yagi and Rastogi, 1979), superoxide dismutase (SOD) (Kakkar et al., 1972) and catalase (Smna, 1972) levels.

\subsection{Histopathological studies}

The liver tissue was dissected out and fixed in $10 \%$ formalin, dehydrated in gradual 
ethanol (50-99\%), cleared in xylene, and embedded in paraffin. Sections were prepared and then stained with hematoxylin and eosin dye.

\subsection{Statistical analysis}

Statistical analysis was performed on a PC using SPSS, V.13, (special package for social sciences). Data are presented as arithmetic mean \pm S.D., The difference among means has been analyzed by oneway ANOVA followed by student $t$ test. A value of $P<0.05$ was considered as statistically significant.

\section{RESULTS}

The results of hepatoprotective effect of water or ethanol extracts on CCl4intoxicated rats are shown in Table 1. In the CCl4 intoxicated group serum AST and ALT were significantly increased as compared to control group $(\mathrm{p}<0.001)$. The elevated activities of serum AST and ALT were significantly reduced in the animal groups treated with either water or ethanolic extracts. Treatment with ethanolic extract showed significantly more activity $(P<0.001)$ than with water extract. Thus, the ethanol extract treated group was superior to the water extract. Results obtained revealed an increase in the level of liver MDA in CCl4- intoxicated rats compared to control group. Treatment with extracts significantly prevented this raise in levels. The activities of SOD and CAT were significantly reduced in the $\mathrm{CCl} 4$ intoxicated group, while they were significantly elevated in the groups pretreated with either extracts. Ethanolic extract has been shown to be more protective than water extract.

Fig 1. Histological examination of liver sections of control animals (Group I) showed normal hepatic cells with wellpreserved cytoplasm prominent nucleus. The livers of CCl4-intoxicated rats showed massive fatty changes, necrosis, and broad infiltration of the lymphocytes. The histological architecture of liver sections of the rats treated with either aqueous or ethanolic extracts showed more or less normal patterns, with a mild degree of fatty change, necrosis and lymphocyte infiltration, almost comparable to those of the control group

\section{DISCUSSION}

Cinnamomum verum belongs to the family Lauraceae and possesses significant ant allergic, antiulcerogenic, antipyretic and anesthetic activities (Kurokawa \& Shiraki, 1998). The bark yields an essential oil containing cinnamaldehyde and eugenol. Several biological activities, such as peripheral vasodilator, antitumor, antifungal, cytotoxic and antimutagenic, have been attributed to cinnamaldehyde (Shaughnessy\& DeMarini, 2001).

Serum AST and ALT activities were used as a marker of liver damage. $\mathrm{CC}_{4}$ produces an experimental damage (James and Pickering, 1976). The toxic metabolite $\cdot \mathrm{CC}_{3}$ radical is produced by cytochrome $\mathrm{p}_{450}$ which further reacts with oxygen to produce trichloromethyl peroxy radicals. These radicals bind covalently with the macromolecule and cause peroxidative degradation of lipid membrane of the liver. The reduction of AST and ALT activities by the extracts is an indication of repair of hepatic tissue damage induced by $\mathrm{CC}_{4}$. This is in agreement with Thabrew et al. (1987), who found that serum transaminases returned to normal activities with the healing of hepatic parenchyma and regeneration of hepatocytes, The ethanolic extract induced suppression of increased ALT and AST activities. Thus, administration of ethanolic or aqueous extracts of cinnamon revealed hepatoprotective activity against the toxic effect of $\mathrm{CCl}_{4}$, which is also supported by histological studies.

Oxidative stress induced due to the generation of free radicals and/or decreased antioxidant level in the target cells and tissues has been suggested to play an important role in carcinogenesis (Huang et al., 1999). During cell membrane damage, various enzymes leak down to the circulatory fluid and their assessment in 
serum serves as markers in clinical studies. SOD is the first antioxidant enzyme to deal with oxyradicals by accelerating the dismutation of superoxide to hydrogen peroxide, while CAT is a peroxisomal hem protein that catalyses the removal of hydrogen peroxide formed during the reaction catalyzed by SOD. Thus, SOD and CAT acts mutually supprtive anti oxidative enzymes, which provide protective defense against reactive oxygen species (Weydert et al., 2006).

\section{TABLE 1}

Antioxidant liver enzyme activities; superoxide dismutase (SOD), catalase, lipid peroxide product (Malendialdlyde), and serum aminotransferase enzymes (ALT and AST) of all studied groups (Mean+SD)

\begin{tabular}{|c|c|c|c|c|}
\hline Animal groups Parameters & normalControl group & $\mathrm{CCI}_{4}$ group & $\mathrm{W} \mathrm{E}+\mathrm{CCI}_{4}$ & $\mathrm{E} \mathrm{E}+\mathrm{CCI}_{4}$ \\
\hline Serum ALTIU/ml & $38.4 \pm 4.56$ & $74.0 \pm 7.86$ & $47.9 \pm 7.14$ & $41.6 \pm 5.08$ \\
\hline $\mathrm{P}_{1}$ value & - & $\mathrm{P}<001$ & $<0.001$ & $<0.001$ \\
\hline $\mathrm{P}_{2}$ value & - & - & $<0.001$ & $<0.05$ \\
\hline $\mathrm{P}_{3}$-value & - & - & - & $<0.05$ \\
\hline Serum ASTIU/ml & $42.4 \pm 4.56$ & $84.0 \pm 7.86$ & $46.9 \pm 7.14$ & $41.6 \pm 5.08$ \\
\hline$P_{1}$ value & - & $\mathrm{P}<001$ & $<0.001$ & $<0.001$ \\
\hline $\mathrm{P}_{2}$ value & - & - & $<0.001$ & $<0.05$ \\
\hline $\mathrm{P}_{3}$-value & - & - & - & $<0.05$ \\
\hline \multicolumn{5}{|l|}{ Malandialdhyde } \\
\hline$(\mathrm{mmol} / \mathrm{mg} /$ protein $)$ Mean $\pm \mathrm{SD}$ & $2.31 \pm 0.14$ & $6.14 \pm 0.57$ & $2.94 \pm 0.27$ & $2.16 \pm 0.32$ \\
\hline $\mathrm{P}_{1}$ value & - & $\mathrm{P}<001$ & $<0.001$ & $<0.001$ \\
\hline $\mathrm{P}_{2}$ value & - & - & $<0.001$ & $<0.01$ \\
\hline $\mathrm{P}_{3}$-value & - & - & - & $<0.05$ \\
\hline \multicolumn{5}{|l|}{ SOD } \\
\hline $\mathrm{MU} / \mathrm{mg}$ proteinMean $\pm \mathrm{SD}$ & $216.8 \pm 13.8$ & $109.5 \pm 34.0$ & $212.7 \pm 25.8$ & $189.3 \pm 23.2$ \\
\hline$P_{1}$ value & - & $\mathrm{P}<001$ & N.S. & $<0.001$ \\
\hline $\mathrm{P}_{2}$ value & - & - & $<0.001$ & $<0.01$ \\
\hline $\mathrm{P}_{3}$-value & - & - & - & $<0.01$ \\
\hline \multicolumn{5}{|l|}{ Catalase } \\
\hline$(\mathrm{nmol} / \mathrm{min} / \mathrm{mg}$ protein $) \mathrm{Mean} \pm \mathrm{SD}$ & $9772.4 \pm 2667.7$ & $2192.0 \pm 146.6$ & $8582.6 \pm 1482.5$ & $4281.3 \pm 935.3$ \\
\hline$P_{1}$ value & - & $\mathrm{P}<001$ & N.S. & $<0.001$ \\
\hline $\mathrm{P}_{2}$ value & - & - & $<0.001$ & $<0.01$ \\
\hline $\mathrm{P}_{3}$-value & - & - & - & $<0.05$ \\
\hline
\end{tabular}

WE. Water extract EE. Ethanol extract

$\mathrm{P}_{1}$ - comparison to normal controlP $\mathrm{P}_{3}$ - water $\mathrm{E}$ versus ethanol $\mathrm{E}$

$\mathrm{P}_{2}$ comparison to $\mathrm{CCl}_{4}$ intoxicated group N.S= not significant 


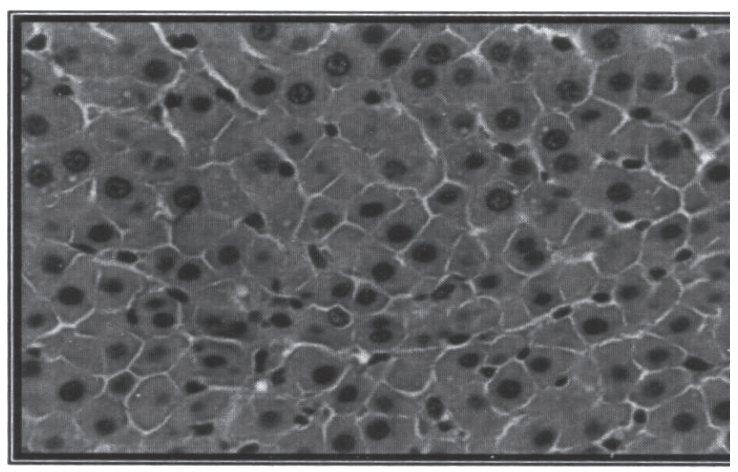

a) control group

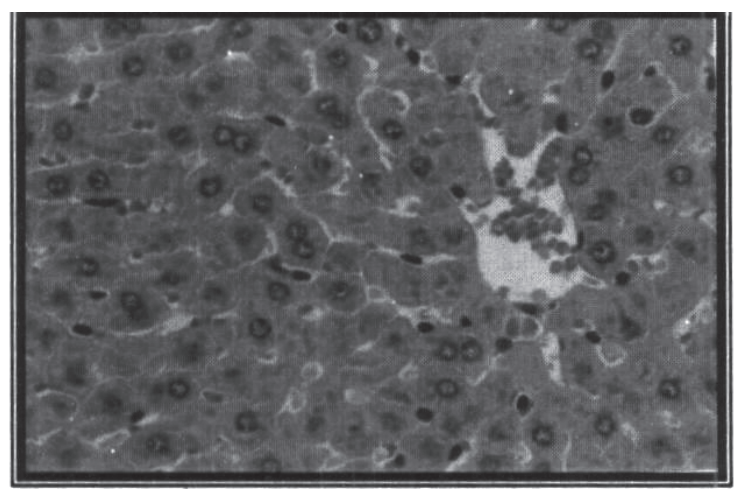

c) $\mathrm{WE}+\mathrm{CCl}_{4}$

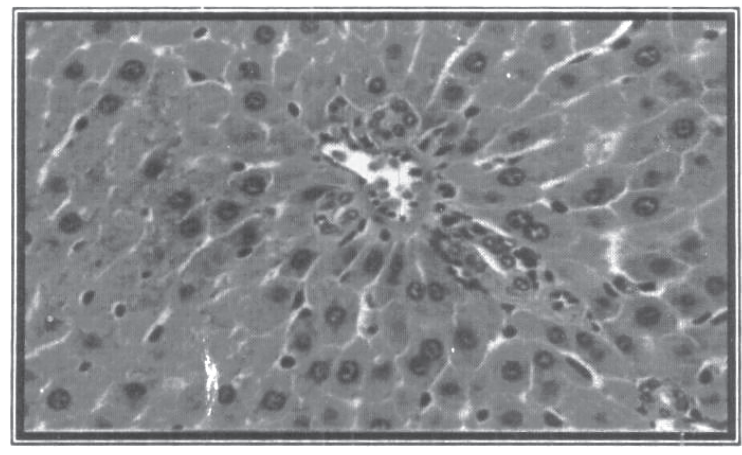

b) $\mathrm{CCl}_{4}$ group

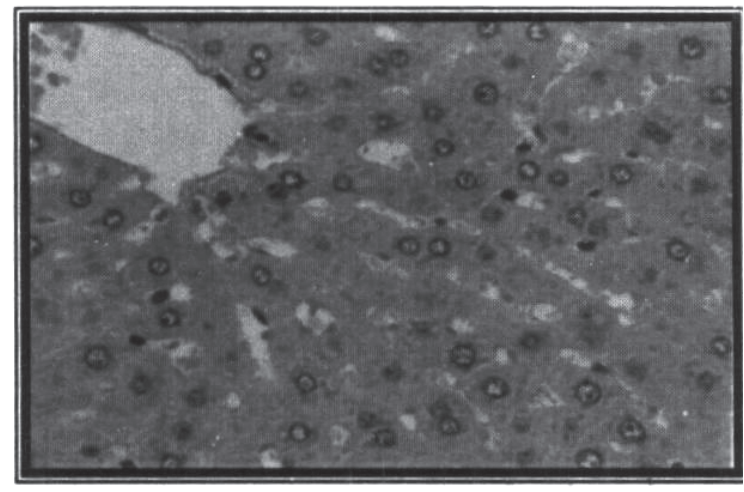

d) $\mathrm{EE}+\mathrm{CCl}_{4}$

Fig. 1: Light micrographs of mice liver treated with $\mathrm{CC} 14$, without and with pretreatment with either water or ethanol extract of cinnamon compared to normal control. Representative sections from (a) normal control liver (b) rats intoxicated with $\mathrm{CC}_{4}$, showing extensive hepatocellular necrosis; and (c) pretreated treated with water E and (d) pretreated with ethanol extract showing absence of hepatocellular necrosis, magnification X 250.

Carbon tetrachloride $(\mathrm{CCl} 4)$ is being used extensively to investigate hepatoprotective activity of different treatments on various experimental animals (Bhathal et al., 1983). A major defense mechanism involves the antioxidant enzymes, including SOD, catalase and glutathione peroxidase (GPx), which convert active oxygen molecules into nontoxic compounds. Lipid peroxidation is accelerated when free radicals are formed as the results of losing a hydrogen atom from the double bond in the structure of unsaturated fatty acids. The free radical scavenging activity of water or ethanolic extracts of cinnamon was evaluated.

Lan et al., (2007) stated that $50 \%$ of acetone extract of cinnamon contained high levels of phenolic groups. Scavenging of free radicals is one of the major antioxidation mechanisms to inhibit the chain reaction of lipid peroxidation. Reduced lipid peroxidation was revealed by a significant decrease in MDA level in groups pretreated with water or ethanol extracts, simultaneously with a significant elevation in SOD and CAT activities.

The present study revealed that SOD and CAT activities decreased in $\mathrm{CCl}_{4}$ injected animal, which may be due to altered antioxidant status. This is in accordance with results that indicated a decreased CAT in $\mathrm{CCl}_{4}$ injected animals may be due to the utilization of antioxidant enzymes in the removal of released $\mathrm{H}_{2} \mathrm{O}_{2}$ released (Cerutti et al.,1994). SOD and CAT activities increased significantly in the treated group versus the untreated animals. 


\section{CONCLUSION}

The results obtained revealed that ethanolic extract of cinnamon has more potent antioxidant activity than water extract. The antioxidant properties of cinnamon extracts are attributable to the ability of its phenolic constituents to quench reactive oxygen species. The hepaoprotective effect is documented by the biochemical and histopathological data obtained. This data supports the uses of cinnamon extract in treatment of some hepatic disorders. Further study will be carried out to identify the types of phenolic compounds present and to test for antitumor activity .

\section{ACKNOWLEDGMENT}

The authors would like to thank Prof. Dr. Taha Koumosani, head of the Biochemistry Department, Faculty of Science, KAU, Jeddah, for kindly facilitating materials for this study.

\section{REFERENCES}

ANDERSON, R. A. \& BROADHURST, C. L. (2004). Isolation and characterization of polyphenol type-A polymers from cinnamon with insulin-like biological activity. Journal of Agricultural and Food Chemistry, $52,65-70$

AVIJEET JAIN, MANISH SONI, LOKESH DEB, ANUREKHA JAIN, S.P. ROUT, V.B. GUPTA, K.L. KRISHNA (2008). Antioxidant and hepatoprotective activity of ethanolic and aqueousextracts of Momordica dioica Roxb. Leaves. Journal of Ethnopharmacology 115 61-66

BHATHAL, P.S., ROSE, N.R., MACKAY, I.R., WHITTINGHAM, S., (1983). Strain differences in mice in carbon tetrachloride-induced liver injury. British Journal of Experimental Pathology 64, 524-533

CERUTTI, R. GHOSH, Y. OYA, P. AMSTAD, The role of cellular antioxidant defence in oxidant carcinogenesis, Environ. Health Perspect. 102 (Suppl. 10) (1994) 123-129

CHATTERJEE, T.K., (2000). Medicinal Plants with Hepatoprotective Properties in Herbal Opinions, vol. III. Books and Allied (P) Ltd., Calcutta, 135

CHATTOPADHYAY, R.R., (2003). Possible mechanism of hepatoprotective activity of Azadirachta indica leaf extract. Part II. Journal of Ethnopharmacology 89, 217 219

GURDIP SINGH, SUMITRA MAURYA, M.P. DELAMPASONA, CESAR A.N. CATALAN (2007). A comparison of chemical, antioxidant and antimicrobial studies of cinnamon leaf and bark volatile oils, oleoresins and their constituents Food and Chemical Toxicology 45. 1650-1661

HUANG Y.L., . SHEU J.Y, .LIN T.H. Association between oxidative stress and changes of trace elements in patients with breast cancer, Clin.Biochem.32 (1999) 31-36

JAMES, G.W.L., PICKERING, R.W., (1976). The protective effect of a novel compound RU-18492 on galactosamine induced hepaptotoxicity in rats. Drug Research 26, 2197-2199

KAKKAR, P., DAS, B., VISVANATHAN, P.N., (1972). A modified spectrophotometric assay of superoxide dismutase. Indian Journal of Biochemistry 197, 588590

KUROKAWA, M., KUMEDA, C. A., YAMAMURA, J., KAMIYAMA, T., \& SHIRAKI, K. (1998). Antipyretic activity of cinnamyl derivatives andrelated compounds in influenza virus infected mice. EuropeanJournal of Pharmacology, 348, 45-51

LAN SU, JUN-JIE YIN, DENYS CHARLES, KEQUAN ZHOU, JEFFREY MOORE LIANGLI. Total phenolic contents, chelating capacities, and radical-scavenging properties of black peppercorn, nutmeg, rosehip, cinnamon and oregano leaf Food Chemistry 100 (2007) 990-997

MURCIA, M. A., EGEA, I., ROMOJARO, F., PARRAS, P., JIMENEZ, A. M., \& MARTINEZ-TOME, M. (2004). Antioxidant evaluation in dessert spices compared with common food additives. Influence of irradiation procedure. Journal of Agricultural and Food Chemistry, 52, 1872-1881

MANCINI-FILHO, J., \& VAN-KOIIJ, A. (1998). Antioxidant activity of cinnamon (Cinnamomum Zeylanicum, Breyne) extracts. Bollettino Chimico Farmaceutico, 137, 443-447

PESCHEL, W., SÁNCHEZ-RABANEDA, F., DICKMANN, W., PLESEHEN, A., GARTIZA, I., JIMÉNEZ, D., LAMUELA-RAVENTOS, R., BUXADERAS, S., CODINA, C., (2006). An Industrial approach in the search of natural antioxidants from vegetables and fruit wastes. Food Chemistry 97, 137-150

REITMAN, S., FRANKEL, S., 1957. A colorimetric method for the determination of serum glutamate oxaloacetate transaminase. American Journal of Clinical Pathology 28, 53-56

REKKA, E., KOUROUNAKIS, P SHAHIDI, F. JANITHA, P.K., WANASUNDARA, P.D., (1992). Phenolic antioxidants. Critical Reviews in Food Science and Nutrition 32, 67-103

SHAUGHNESSY, D. T., SETZER, R. W., \& DEMARINI, D. M. (2001). The antimutagenic effect of vanillin and cinnamaldehyde on spontaneous mutation in Salmonella TA 104 is due to a reduction in mutations at GC but not AT sites. Mutation Research, 480/481, $55-69$

SMNA, K.A., 1972. Colourimetric assay of catalase. Analytical Biochemistry 47, 389-394

THABREW, M.I., JOICE, P.D.T.M., RAJATISSA, W.A., (1987). Comparative study of efficacy of Paetta indica and Osbeckia octandra in the treatment of liver dysfunction. Planta Medica 53, 239-241

VEKIARI, S. A., OREOPOULOU, V., TZIA, C., \& THOMOPOULOS, C. D. (1993). Oregano flavonoids as lipid antioxidants. Journal of the American Oil Chemists_Society, 70, 483-487

WEYDERT C.J., WAUGH T.A., .RITCHIE J.M, IYER K.S., SMITH J.L. L.LI, D.R. SPITZ, L.W.OBERLEY, overexpression of manganese or copper-zinc superoxide dismutase inhibits breat cancer growth, Free Rad.Biol.med.41 (2006) 226-237

YAGI, K., RASTOGI, R., (1979). Assay for lipid peroxides in animal tissues by thiobarbituric acid reaction. Analytical Biochemistry 95, 351-358 